\title{
Distribution of Different Forms of Soil Acidity in Selective Laterite Soils under Cashew Plantations in Coastal Karnataka
}

\author{
R. Srinivasan ${ }^{1 *}$, A. Natarajan², K. S. Anil kumar², S. Dharumarajan² and D. Kalaivanan ${ }^{3}$ \\ ${ }^{1}$ ICAR-NBSS\&LUP, Regional Centre, Sector-II, Block-DK, Salt Lake, Kolkata, West Bengal (700 091), India \\ ${ }^{2}$ ICAR-NBSS\&LUP, Regional Centre, Hebbal, Bangaluru (560 024), India \\ ${ }^{3}$ ICAR-Indian Institute of Horticultural Research, Hesaraghatta, Bengaluru, Karnataka (560 089), India
}

\section{Article History}

Manuscript No. 1498

Received in $27^{\text {th }}$ November, 2015

Received in revised form $29^{\text {th }}$ March, 2016

Accepted in final form $5^{\text {th }}$ April, 2016

\section{Correspondence to}

"E-mail: srinivasan.surya@gmail.com

\section{Keywords}

Illuvation, acidity, pedon, lime requirement and cashew

\begin{abstract}
A study was conducted to examine soil morphological, physico-chemical properties and different forms of soil acidity of six selected laterite soils under cashew plantations in coastal Karnataka. Pedons were dug to a depth of $2 \mathrm{~m}$ at six selected locations viz. Pala hillock, DCR-Shanthigodu, Muchipadavu, Mulia, ARS-Ullal and Palikudel and horizon wise samples were collected to study the various soil parameters including different forms of soil acidity. Cation exchange capacity and base saturation of the soils were varied from 7.60 to $19.8 \mathrm{cmol}\left(\mathrm{p}^{+}\right) \mathrm{kg}^{-1}$ and 4 to $32 \%$, respectively. The exchangeable acidity varied from 0.06 to $\left.2.20 \mathrm{cmol}^{(\mathrm{p}+}\right) \mathrm{kg}^{-1}$ and extractable acidity ranged from 8.16 to $47.89 \mathrm{cmol}\left(\mathrm{p}^{+}\right) \mathrm{kg}^{-1}$. Presence of low exchangeable acidity could be due to efficient recycling of basic cations and higher exchangeable acidity in few locations may be due to the presence of exchangeable ions like $\mathrm{H}^{+}$and $\mathrm{Al}^{3+}$. Results obtained from this study indicated that the Pedons 1, 4, 5 and 6 requires more lime than others to reclaim for maximizing cashew production by restoring the available soil nutrients.
\end{abstract}

\section{Introduction}

Cashew is a major export crop in India with highest percentage of exports coming from Western parts of coastal India, majorly from coastal Karnataka. However, the production has dwindled in recent decades due to variable climatic and soil constraints (Bhat, 2007). From the coastal regions cashew was introduced to the plains of Karnataka, Chhattisgarh and in the hilly areas of Eastern states. Although area under cashew has been steadily increasing in India in the recent year, its production is not satisfactory in most part of the country. Cashew is mostly grown on laterite and red soils and coastal sandy in the states, which are very poor in fertility and the yields are low in these soils unless the trees are fertilized regularly (Anon, 2003). Major problems are shallow depth, coarse texture and severe acidity. Soil acidification and related land degradation are becoming more important worldwide and are challenging the concept of sustainability of current land management system (Noble et al., 2000).

Acid soils cover about 49 mha, approximately $34 \%$ of cropped land in India (Maji et al., 2012). The acid soils ( $\mathrm{pH}<6.5)$ occupy approximately 90 mha of the geographical area (Sharma and Sarkar, 2005). Strongly acidic soils (below pH 5.5) occupy around 25 mha of arable land in India. Such type of problematic soils in India are mainly concentrated in North-Eastern (NE) region and Western Ghats, Jharkhand, Chhatisgarh, Uttarakhand with sporadic distribution in Himachal Pradesh, Orissa and West Bengal, etc (Panda, 1987). Soil acidity has been recognized as an important agricultural problem, which adversely affects the crop production, directly or indirectly. Cashew production involves a complex interaction between the environment, soil parameters, and nutrient dynamics. Because of this fact, the soil must be studied in terms of the productive potentials. Failure to understand these complexities has resulted in lack of good crop production and management techniques; hence agricultural production has tended to be low. Soil fertility decline is considered as an important cause for low productivity of many soils (Sanchez, 2002). Assessing soil fertility decline is difficult because most soil chemical properties either change very slowly or have large seasonal fluctuations. This decline includes; nutrient depletion, nutrient mining, acidification (decline in $\mathrm{pH}$ and or an increase in exchangeable $\mathrm{Al}$ ), loss of organic matter and increase in toxic elements (e.g. Al, Mn) (Hartemink, 2006). Soil acidity constitutes one of the important factors, which influence the chemistry as well as fertility management of tropical soils like laterite soils. These acidity 
parameters will help us in understanding the rate at which the process of laterisation proceeds in a particular land use system (Chenithung et al., 2014). Since, not much study has done in the laterite soils of coastal Karnataka on different forms of soil acidity effect on cashew production. Hence, the study was aimed at understanding the various soil acidity parameters of six selected laterite soils along with other soil properties under cashew from coastal Karnataka.

\section{Materials and Methods}

\subsection{Study area selection}

A case study was undertaken in four taluks of Dakshina Kannada district of Coastal Karnataka in during 2012-13 (Table 1). The geology of the area consists of rock formation of archean complex (archean granites and gneisses) with sparse bands of dharwar system of rocks which are capped by laterite at many places. The study area is included in the coastal zone of Karnataka that comprises two major geomorphological zones viz. Fluvio-littoral formation and dissected hilly hinter land (Dasog and Patil, 2002).

\subsection{Climatic conditions of the study area}

Study area represents hot and humid climate with annual precipitation ranged from 3592 to $3842 \mathrm{~mm}$. The maximum and minimum temperature of the study area recorded was $36^{\circ} \mathrm{C}$ and $20^{\circ} \mathrm{C}$ respectively. Relative humidity varied from 76 to $97 \%$, due to low altitude. Mean annual potential evaporation was also very high $(>1000)$ especially in the coastal region. The rainfall distribution during May to November month was frequent, with heavy rainfall recorded during July in all the

\begin{tabular}{|c|c|c|c|}
\hline Taluk & Village & Land use & $\begin{array}{c}\text { Yield } \\
\left(\mathrm{kg} \mathrm{ha}^{-1}\right)\end{array}$ \\
\hline 1. Puttur & $\begin{array}{c}\text { Pala } \\
\text { hillock }\end{array}$ & $\begin{array}{l}\text { Forest with plantation } \\
\text { of cashew }\end{array}$ & 725 \\
\hline 2. Puttur & $\begin{array}{l}\text { DCR- } \\
\text { Shanth- } \\
\text { igodu }\end{array}$ & $\begin{array}{l}\text { Well maintained } \\
\text { cashew farm with } \\
\text { intercrops of } \\
\text { pineapple and onion }\end{array}$ & 690 \\
\hline 3. Bantwal & $\begin{array}{l}\text { Muchi- } \\
\text { padavu }\end{array}$ & $\begin{array}{l}\text { Poorly maintained } \\
\text { cashew plantation with } \\
\text { other tree species }\end{array}$ & 685 \\
\hline 4. Bantwal & Mulia & $\begin{array}{l}\text { Degraded cashew } \\
\text { plantation in the } \\
\text { hillock }\end{array}$ & 461 \\
\hline $\begin{array}{l}\text { 5. Manga- } \\
\text { lore }\end{array}$ & $\begin{array}{l}\text { ARS- } \\
\text { Ullal }\end{array}$ & $\begin{array}{l}\text { Well maintained } \\
\text { cashew farm }\end{array}$ & 710 \\
\hline 6. Karkala & $\begin{array}{l}\text { Paliku- } \\
\text { del }\end{array}$ & $\begin{array}{l}\text { Patches of cashew } \\
\text { plantation with tree } \\
\text { species and shrubs }\end{array}$ & 425 \\
\hline
\end{tabular}

study location. Length of dry season is less about four months and length of crop growing period is about 190 to 210 days. Water balance diagrams were prepared using method suggested by Thornthwaite and Mather (1955) and model of Higgins and Kassam (1981), which is used for estimating of water deficit, water surplus and moisture index, which could be useful to determine the water surplus and deficient periods (Figure 1).

\subsection{Soil sampling and analysis}

Soil samples collected from horizon wise of all profiles were dried in air and then crushed in wooden mortar with a wooden pestle and sieved through $2 \mathrm{~mm}$ sieve to separate the coarse fragments $(>2 \mathrm{~mm})$. The fine earth samples were stored in separate containers and used for analysis. Particlesize analysis of the samples was carried out by international pipette method. Electrical conductivity, $\mathrm{pH}$, cation exchange capacity and base saturation were determined using standard methods (Jackson, 1973). Exchangeable Hydrogen and Aluminium together constitute the exchangeable acidity of the soil. These exchangeable acid cations were extracted using $1.0 \mathrm{~N} \mathrm{KCl}$ and total exchangeable acidity was determined by titrating with standard alkali $(\mathrm{NaOH})$ solution. Exchangeable aluminium was determined by treating the titrated solution with excess potassium fluoride and then titrating with standard sulphuric acid until the pink colour disappears. Exchangeable hydrogen was calculated by difference (Sarma et al., 1987). Extractable acidity was determined by using barium chloridetriethanolamine. The soil buffer mixture was shaken in an end to end shaker for 16 hours, the contents centrifuged and the clear supernatant was titrated against standard $\mathrm{HCl}$ using bromocresol green as indicator (Sarma et al., 1987). Lime requirement was done by treating soil with a SMP buffer (1.8 g paranitrophenol, $2.5 \mathrm{ml}$ of TEA, $3 \mathrm{~g}$ of potassium chromate, $2 \mathrm{~g}$ calcium acetate and $53.1 \mathrm{~g}$ of $\mathrm{CaCl}_{2}$ dissolved in one litre of water with $\mathrm{pH}$ 7.5) solution and the lime requirement was calculated from the reduction in $\mathrm{pH}$ of the buffer (Shoemaker et al., 1961).

\section{Results and Discussion}

\subsection{Soil morphological characteristics}

Brief morphological features of the pedons are presented in Table 2. The solum depth varied from deep to very deep. Pedons had their Munsell colour notation in the hue of $10 \mathrm{YR} / 7.5 \mathrm{YR} / 5 \mathrm{YR} / 2.5 \mathrm{YR}$ with value 3 to 4 and chroma 4 to 8 . The soil colour appears to be the function of chemical and mineralogical composition as well as textural make up of soils and conditioned by topographic position and moisture regime (Shiva prasad et al., 1998). Pedons 1, 2, 4 and 6 had dark brown colour in surface soils and dark red to red colour in sub soils. In pedon 3 and 5, surface soil colors were yellowish red and dark reddish brown and whereas the sub soil colour was 
red. All the layers of various pedons contained high amount of gravel percentage, which increased with increasing depth. In all the pedons texture varied from sandy clay loam to clay and clay content were varied from 24.5 to $66.4 \%$. Low clay content in the surface horizons might be due to the illuvation or translocation of clay from the surface to subsurface horizons. The wide textural variation might be due to variation in soil formation, in situ weathering. Clay skin or cutans distribution

Table 2: Morphological characteristics of the soils

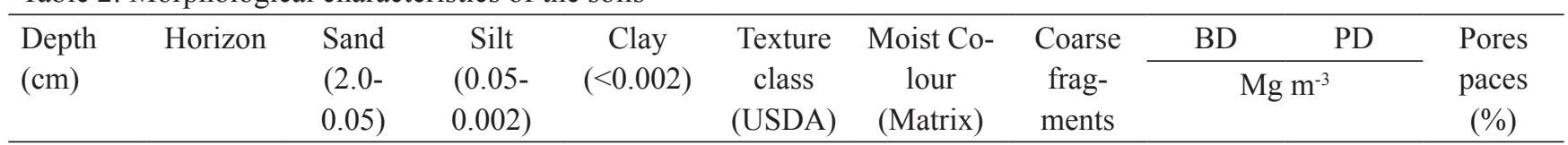

Pedon 1 (Loamy- skeletal, mixedisohyperthermic Ustic Haplohumults)

\begin{tabular}{lcccccccccc}
\hline $0-21$ & A1 & 58.9 & 15.6 & 25.5 & scl & 7.5 YR 3/4 & 10 & 1.42 & 2.48 & 43 \\
$21-41$ & Bt1 & 55.1 & 9.4 & 35.5 & sc & 7.5 YR 3/4 & 20 & 1.33 & 2.57 & 48 \\
$41-68$ & Bt2 & 62.2 & 6.4 & 31.4 & scl & 5YR 3/4 & 50 & 1.38 & 2.60 & 47 \\
$68-95$ & Bt3 & 57.8 & 9.9 & 32.3 & scl & 2.5 YR 3/6 & 40 & 1.38 & 2.64 & 48 \\
$95-123$ & Bt4 & 59.5 & 11.3 & 29.2 & scl & 2.5 YR 3/6 & 60 & 1.57 & 2.69 & 42
\end{tabular}

Pedon 2 (Fine, mixed, isohyperthermic Oxic Dystrustepts)

\begin{tabular}{lcccccccccc}
\hline $0-19$ & Ap & 38.6 & 8.9 & 52.5 & c & 7.5 YR 3/4 & 30 & 1.44 & 2.54 & 43 \\
$19-42$ & Bw1 & 36.8 & 12.6 & 50.6 & c & 2.5 YR 3/6 & 30 & 1.49 & 2.52 & 41 \\
$42-71$ & Bw2 & 33.6 & 15.3 & 51.2 & c & 2.5 YR 3/6 & 80 & 1.45 & 2.52 & 42 \\
$71-90$ & Bc & 44.0 & 13.9 & 42.1 & c & $2.5 Y R 4 / 6$ & 80 & 1.50 & 2.59 & 42
\end{tabular}

Pedon 3 (Fine, mixed, isohyperthermic Oxic Dystrustepts)

\begin{tabular}{lcccccccccc}
\hline $0-25$ & Ap & 26.7 & 10.2 & 63.0 & c & 5 YR 4/6 & 35 & 1.27 & 2.56 & 50 \\
$25-50$ & Bw1 & 21.4 & 13.6 & 65.1 & c & 2.5 YR 3/6 & 25 & 1.21 & 2.55 & 52 \\
$50-84$ & Bw2 & 23.3 & 14.6 & 62.1 & c & 2.5 YR 3/6 & 20 & 1.13 & 2.49 & 54 \\
$84-128$ & Bw3 & 16.3 & 17.3 & 66.4 & c & 2.5 YR 3/6 & 15 & 1.13 & 2.48 & 54 \\
$128-160$ & Bw4 & 21.2 & 20.5 & 58.3 & c & 2.5 YR 3/6 & 15 & 1.14 & 2.49 & 54
\end{tabular}

Pedon 4 (Clayey-skeletal, mixed isohyperthermic Ustic Haplohumults)

\begin{tabular}{|c|c|c|c|c|c|c|c|c|c|c|}
\hline $0-17$ & $\mathrm{~A}$ & 37.2 & 22.2 & 40.6 & $\mathrm{c}$ & 7.5 YR $3 / 4$ & 40 & 1.31 & 2.48 & 47 \\
\hline $17-41$ & Bt1 & 28.0 & 19.6 & 52.4 & $\mathrm{c}$ & 7.5YR 3/4 & 60 & 1.23 & 2.48 & 50 \\
\hline $41-60$ & $\mathrm{Bt} 2$ & 29.4 & 9.4 & 61.2 & $\mathrm{c}$ & $2.5 \mathrm{YR} 3 / 6$ & 70 & 1.36 & 2.50 & 45 \\
\hline $60-90$ & $\mathrm{Bt} 3$ & 37.1 & 5.0 & 57.9 & $\mathrm{c}$ & $2.5 \mathrm{YR} 4 / 6$ & 70 & 1.23 & 2.54 & 51 \\
\hline $90-155$ & $\mathrm{BC}$ & 50.3 & 10.9 & 38.8 & $\mathrm{c}$ & $2.5 \mathrm{YR} 4 / 6$ & 70 & 1.20 & 2.51 & 52 \\
\hline \multicolumn{11}{|c|}{ Pedon 5 (Clayey-skeletal, mixed isohyperthermic Typic Rhodustults) } \\
\hline $0-20$ & Ap & 61.0 & 6.8 & 32.2 & $\mathrm{cl}$ & $5 Y R 3 / 4$ & 20 & 1.33 & 2.58 & 48 \\
\hline $20-40$ & $\mathrm{Bw}$ & 56.8 & 7.4 & 35.8 & $\mathrm{sc}$ & $2.5 \mathrm{YR} 3 / 6$ & 40 & 1.36 & 2.62 & 48 \\
\hline $40-70$ & Bt1 & 49.6 & 6.2 & 44.2 & $\mathrm{sc}$ & $2.5 Y R 3 / 6$ & 60 & 1.52 & 2.52 & 40 \\
\hline 70-99 & $\mathrm{Bt} 2$ & 41.1 & 6.8 & 52.1 & $\mathrm{c}$ & $2.5 \mathrm{YR} 3 / 4$ & 60 & 1.60 & 2.53 & 37 \\
\hline $99-127$ & $\mathrm{Bt} 3$ & 46.8 & 5.0 & 48.2 & $\mathrm{sc}$ & $2.5 \mathrm{YR} 4 / 8$ & 70 & 1.60 & 2.49 & 36 \\
\hline $127-165$ & $\mathrm{Bt} 4$ & 50.3 & 4.3 & 45.4 & $\mathrm{sc}$ & $2.5 \mathrm{YR} 4 / 8$ & 60 & 1.58 & 2.53 & 37 \\
\hline \multicolumn{11}{|c|}{ Pedon 6 (Clayey-skeletal, mixed, isohyperthermic Ustic Palehumults) } \\
\hline $0-28$ & A & 66.8 & 8.7 & 24.5 & scl & $7.5 \mathrm{YR} 3 / 4$ & 30 & 1.30 & 2.50 & 48 \\
\hline $28-55$ & Bt1 & 50.5 & 12.3 & 37.2 & $\mathrm{sc}$ & $5 Y R 3 / 6$ & 35 & 1.44 & 2.60 & 45 \\
\hline $55-90$ & $\mathrm{Bt} 2$ & 48.7 & 11.2 & 40.1 & $\mathrm{sc}$ & $2.5 \mathrm{YR} 3 / 6$ & 40 & 1.44 & 2.65 & 45 \\
\hline $90-130$ & $\mathrm{Bt} 3$ & 43.5 & 12.5 & 44.0 & $\mathrm{c}$ & $2.5 \mathrm{YR} 4 / 6$ & 40 & 1.47 & 2.57 & 43 \\
\hline $130-180$ & $\mathrm{Bt} 4$ & 43.5 & 11.3 & 45.2 & $\mathrm{c}$ & 2.5 YR 4/6 & 50 & 1.43 & 2.68 & 46 \\
\hline
\end{tabular}


of the profiles were unable to notice due to high rainfall in the study area. Based on the laboratory analysis on clay content, CEC and base saturation, it was found that the pedons 1, 4, 5 and 6 had argillic endopedons and pedon 2 and 3 had cambic endopedons. The bulk density, particle density and porosity ranged from 1.13 to $1.67,1.30$ to $1.69 \mathrm{Mg} \mathrm{m}^{-3}$ and 36 to $54 \%$ respectively. The irregular trend of porosity with depth was due to the illuviation and eluviation processes of finer fractions in to different horizons (Chadhaand Nair, 1998; Bhattacharyya et al., 2009).

\subsection{Physico-chemical characteristics}

The detailed physico-chemical characteristics of the soils are given in Table 3. All the pedons were moderately to strongly acidic with $\mathrm{pH}$ ranging from 4.8 to 6.0. The acidic nature of the soil might be attributed mainly to the leaching of the bases due to the existing high rainfall conditions and to some extend may contributed from acidic parent materials. (Shivaprasad et al., 1998) while characterizing the soils of Karnataka observed that the soils derived from granite-gnesis parent materials were found to be slightly acidic to near neutral in soil reaction. The organic carbon content of the soils was found to be high in surface soils and low in sub surface soils. The organic carbon content was decreased with increasing depth. This is attributed to the addition of plant residues and farmyard manure to surface horizons (Sivasankaran et al., 1993). Cation exchange capacity and base saturation varied from 7.6 to $33.6 \mathrm{cmol}\left(\mathrm{p}^{+}\right) \mathrm{kg}^{-1}$ and 7 to $34 \%$ respectively, which showed decreasing trend with increasing depth of soil (Dey and Sehgal, 1997; Patton et al., 2007).

\begin{tabular}{|c|c|c|c|c|c|c|c|c|c|c|c|c|c|c|c|c|c|}
\hline \multirow[t]{3}{*}{$\begin{array}{l}\text { Depth } \\
\text { (cm) }\end{array}$} & \multirow[t]{3}{*}{$\begin{array}{l}\text { Ho- } \\
\text { ri- } \\
\text { zon }\end{array}$} & \multicolumn{3}{|c|}{$\mathrm{pH}(1: 2.5)$} & \multirow[t]{3}{*}{$\begin{array}{c}\mathrm{EC} \\
(\mathrm{dS} / \mathrm{m})\end{array}$} & \multirow[t]{3}{*}{$\begin{array}{l}\mathrm{OC} \\
(\%)\end{array}$} & \multicolumn{3}{|c|}{$\begin{array}{c}\text { CEC } \\
\left(\mathrm{cmol}\left(\mathrm{p}^{+}\right) \mathrm{kg}^{-1}\right)\end{array}$} & \multirow[t]{3}{*}{$\begin{array}{l}\text { BS } \\
(\%)\end{array}$} & \multirow{2}{*}{$\begin{array}{c}\text { Ex- } \\
\text { tract- } \\
\text { able } \\
\text { acidity } \\
\left(\mathrm{BaCl}_{2}-\right. \\
\text { TEA } \\
\text { pH 8.2) }\end{array}$} & \multicolumn{3}{|c|}{$\begin{array}{c}\text { Exchangeable } \\
\text { acidity } \\
1.0 \mathrm{M} \mathrm{KC}_{1}\end{array}$} & \multicolumn{3}{|c|}{$\begin{array}{l}\text { Requirement } \\
\text { of lime to } \\
\text { bring the soil } \\
\text { to desired } \mathrm{pH} \\
\quad\left(\mathrm{t} \mathrm{ac}^{-1}\right)\end{array}$} \\
\hline & & \multirow[t]{2}{*}{$\mathrm{H}_{2} \mathrm{O}$} & \multirow[t]{2}{*}{$\begin{array}{c}1.0 \mathrm{M} \\
\mathrm{KCl}\end{array}$} & \multirow[t]{2}{*}{$\begin{array}{l}0.01 \mathrm{M} \\
\mathrm{CaCl}_{2}\end{array}$} & & & \multirow{2}{*}{$\begin{array}{c}\mathrm{NH}_{4} \mathrm{OAc} \\
\mathrm{pH} \\
7.0\end{array}$} & \multirow{2}{*}{$\begin{array}{l}\text { Sum } \\
\text { of } \\
\text { cation }\end{array}$} & \multirow[t]{2}{*}{ ECEC } & & & \multirow[t]{2}{*}{$\mathrm{H}^{+}$} & \multirow[t]{2}{*}{$\mathrm{Al}^{3+}$} & \multirow[t]{2}{*}{$\begin{array}{l}\text { To- } \\
\text { tal }\end{array}$} & \multirow[t]{2}{*}{6.0} & & \multirow[t]{2}{*}{6.8} \\
\hline & & & & & & & & & & & & & & & & & \\
\hline \multicolumn{18}{|c|}{ Pedon-1 (Loamy- skeletal, mixed isohyperthermic Ustic Haplohumults) } \\
\hline $0-21$ & A1 & 5.4 & 4.2 & 4.5 & 0.05 & 3.07 & 15.5 & 51.79 & 4.23 & 25 & 47.8 & 0.55 & 0.33 & 0.88 & 4.4 & 5.2 & 6.0 \\
\hline $21-41$ & Bt1 & 5.3 & 4.0 & 4.1 & 0.01 & 1.53 & 14.7 & 33.04 & 2.54 & 7 & 31.9 & 0.45 & 1.46 & 1.91 & 3.9 & 4.7 & 5.4 \\
\hline $41-68$ & Bt2 & 5.6 & 4.0 & 4.2 & 0.01 & 0.38 & 13.1 & 19.59 & 2.30 & 12 & 17.9 & 0.39 & 0.61 & 1.00 & 1.8 & 2.2 & 2.5 \\
\hline $68-95$ & $\mathrm{Bt} 3$ & 5.6 & 4.1 & 4.3 & 0.01 & 0.32 & 11.9 & 18.14 & 1.49 & 10 & 16.9 & 0.25 & 0.27 & 0.52 & 1.0 & 1.2 & 1.4 \\
\hline $95-123$ & Bt4 & 5.7 & 4.4 & 4.6 & 0.01 & 0.13 & 7.7 & 13.04 & 1.46 & 16 & 11.7 & 0.0 & 0.0 & 0.0 & 0.0 & 0.0 & 0.0 \\
\hline \multicolumn{18}{|c|}{ Pedon-2 (Fine, mixed, isohyperthermic Oxic Dystrustepts) } \\
\hline $0-19$ & Ap & 5.5 & 4.3 & 4.4 & 0.02 & 1.68 & 12.4 & 28.01 & 3.88 & 31 & 24.4 & 0.0 & 0.0 & 0.0 & 2.3 & 2.7 & 3.1 \\
\hline $19-42$ & Bw1 & 5.6 & 4.5 & 4.6 & 0.01 & 0.97 & 11.0 & 21.03 & 1.43 & 13 & 19.6 & 0.0 & 0.0 & 0.0 & 1.0 & 1.2 & 1.4 \\
\hline $42-71$ & Bw2 & 5.7 & 4.0 & 5.0 & 0.01 & 0.70 & 8.6 & 17.60 & 1.64 & 19 & 15.9 & 0.0 & 0.0 & 0.0 & 0.0 & 0.0 & 0.0 \\
\hline $71-90$ & $\mathrm{Bc}$ & 6.0 & 5.3 & 5.3 & 0.01 & 0.14 & 7.6 & 16.43 & 2.0 & 26 & 14.4 & 0.0 & 0.0 & 0.0 & 0.0 & 0.0 & 0.0 \\
\hline \multicolumn{18}{|c|}{ Pedon-3 (Fine, mixed, isohyperthermic Oxic Dystrustepts) } \\
\hline $0-25$ & Ap & 5.5 & 4.2 & 4.2 & 0.01 & 0.97 & 10.2 & 23.72 & 2.59 & 20 & 21.63 & 0.33 & 0.50 & 0.83 & 1.4 & 1.7 & 1.9 \\
\hline $25-50$ & Bw1 & 5.3 & 4.3 & 4.3 & 0.01 & 0.82 & 8.0 & 26.44 & 3.04 & 34 & 23.73 & 0.28 & 0.33 & 0.61 & 1.0 & 1.2 & 1.4 \\
\hline $50-84$ & Bw2 & 5.5 & 4.5 & 4.4 & 0.02 & 0.50 & 7.8 & 22.29 & 1.41 & 18 & 20.88 & 0.0 & 0.0 & 0.0 & 1.0 & 1.2 & 1.4 \\
\hline $84-128$ & Bw3 & 5.3 & 4.5 & 4.3 & 0.00 & 0.40 & 10.2 & 20.19 & 1.37 & 13 & 18.82 & 0.0 & 0.0 & 0.0 & 1.0 & 1.2 & 1.4 \\
\hline $128-160$ & Bw4 & 5.4 & 4.7 & 4.4 & 0.03 & 0.26 & 9.8 & 15.99 & 1.39 & 14 & 14.60 & 0.0 & 0.0 & 0.0 & 0.0 & 0.0 & 0.0 \\
\hline \multicolumn{18}{|c|}{ Pedon-4 (Clayey-skeletal, mixed isohyperthermic Ustic Haplohumults) } \\
\hline $0-17$ & A & 5.5 & 4.3 & 4.4 & 0.29 & 2.80 & 19.8 & 44.4 & 3.5 & 11 & 42.0 & 0.21 & 1.23 & 1.44 & 3.1 & 3.7 & 4.2 \\
\hline $17-41$ & Bt1 & 5.4 & 4.2 & 4.3 & 0.05 & 2.04 & 14.8 & 40.8 & 3.2 & 15 & 38.6 & 0.77 & 0.96 & 1.73 & 3.5 & 4.2 & 4.8 \\
\hline $41-60$ & Bt2 & 5.5 & 4.2 & 4.3 & 0.01 & 1.42 & 14.3 & 31.8 & 3.6 & 18 & 29.3 & 0.12 & 1.07 & 1.19 & 3.1 & 3.7 & 4.2 \\
\hline $60-90$ & $\mathrm{Bt} 3$ & 5.5 & 4.3 & 4.4 & 0.02 & 0.65 & 9.1 & 30.7 & 3.3 & 32 & 27.8 & 0.42 & 0.39 & 0.81 & 1.4 & 1.7 & 1.9 \\
\hline $90-155$ & $\mathrm{BC}$ & 5.3 & 4.5 & 4.6 & 0.04 & 0.43 & 10.7 & 21.8 & 1.9 & 18 & 19.8 & 0.0 & 0.0 & 0.0 & 1.4 & 1.7 & 1.9 \\
\hline
\end{tabular}




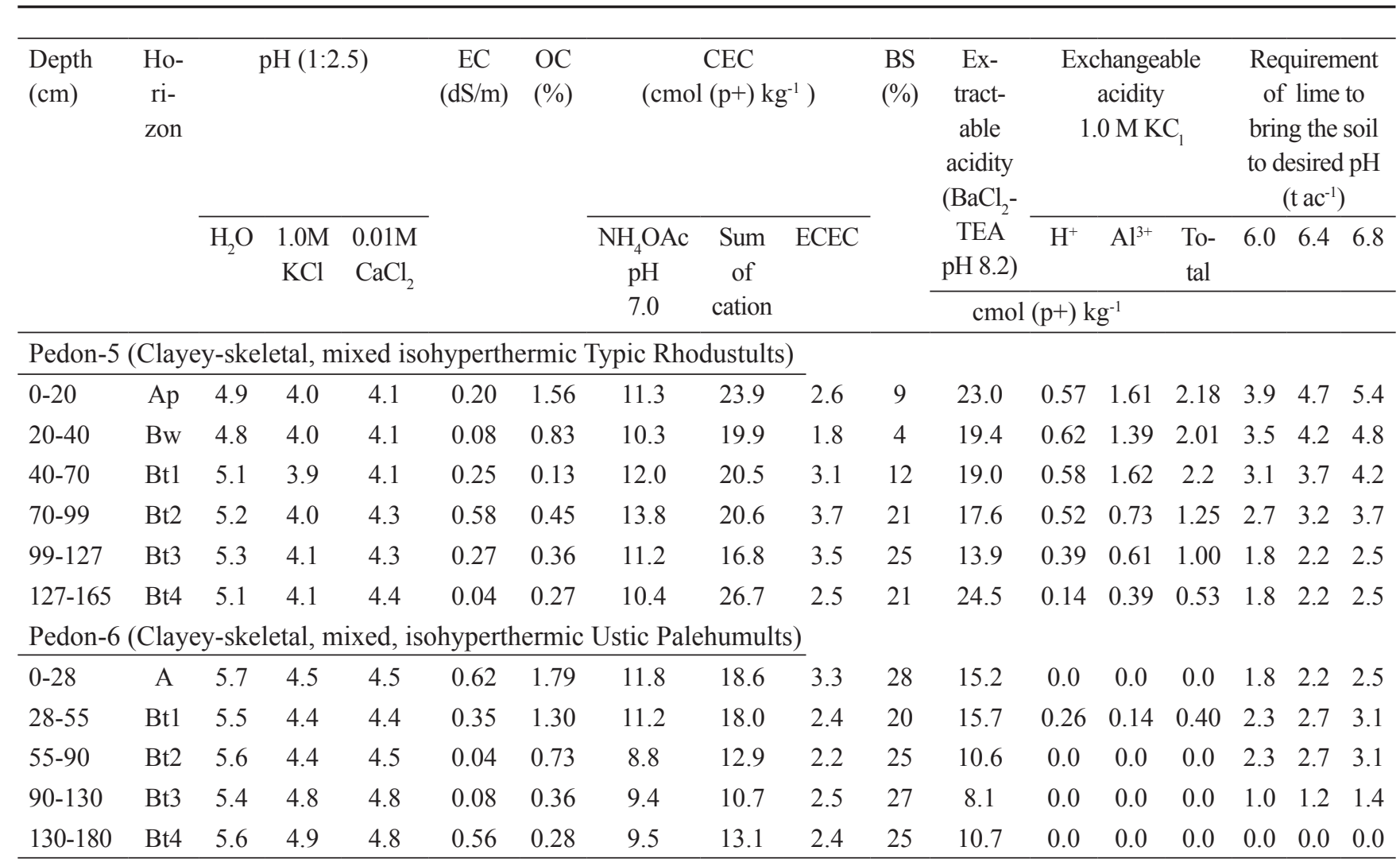

\subsection{Soil acidity characteristics}

Exchangeable acidity and extractable acidity varied from 0.06 to $2.20 \mathrm{cmol}(\mathrm{p}+) \mathrm{kg}^{-1}$ and 8.16 to $47.89 \mathrm{cmol}\left(\mathrm{p}^{+}\right) \mathrm{kg}^{-1}$.
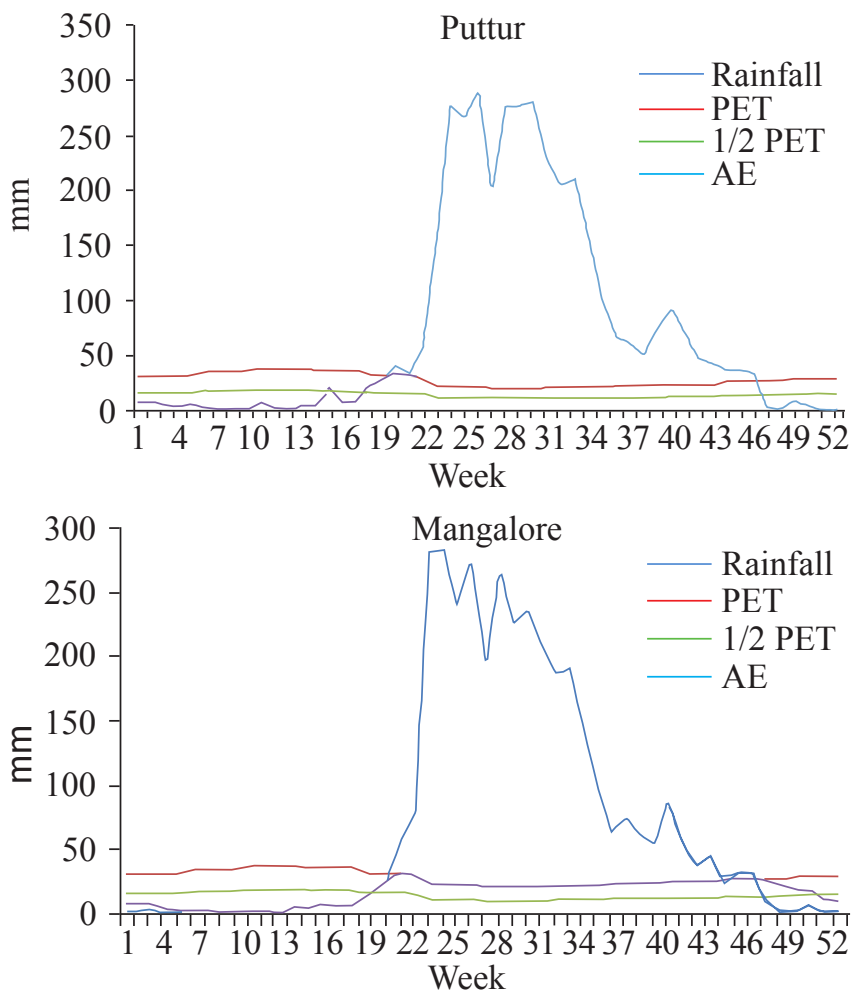

The values were decreased with increasing depth of the all the soil profiles, more acid extract was found in less than 40 $\mathrm{cm}$ depth of soil (Table 3 ). Low exchangeable acidity could
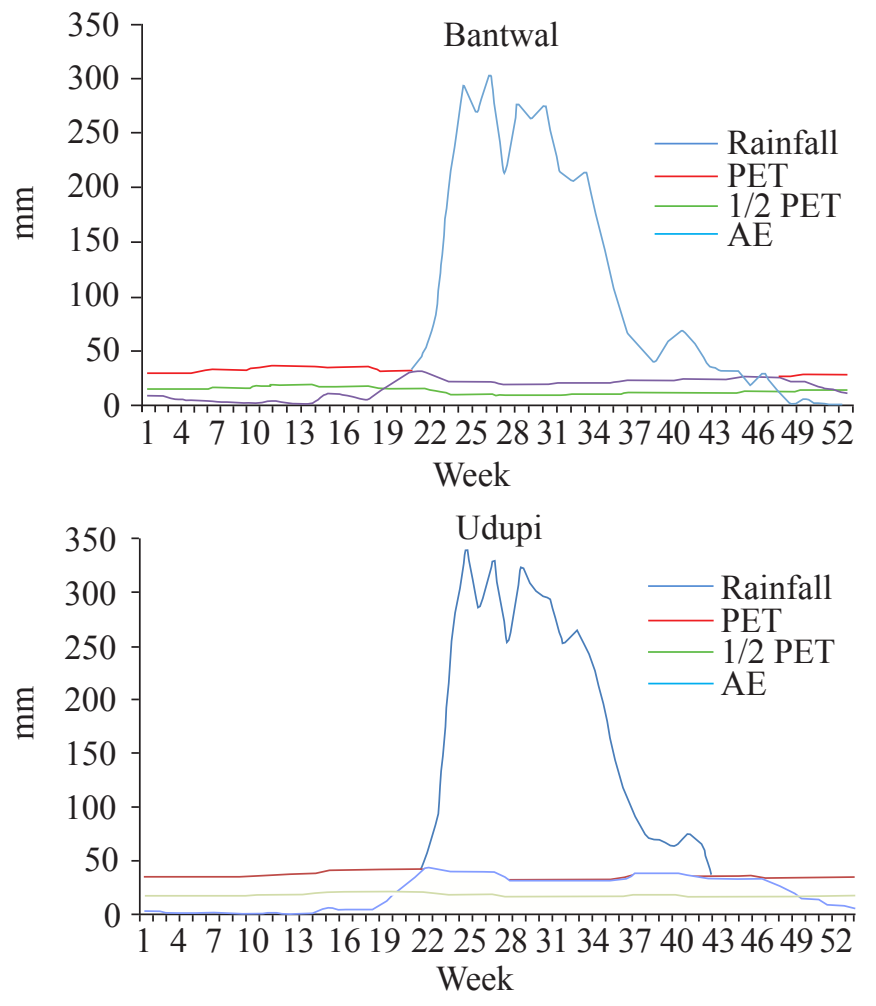
be due to efficient recycling of basic cations which facilitates the soil to maintain a higher $\mathrm{pH}$ and low exchangeable acidity and aluminium (Talashilkar et al., 2006; Amenla et al., 2010). Higher exchangeable acidity in few locations could be due to the presence of exchangeable ions like $\mathrm{H}^{+}$and $\mathrm{A}^{13+}$ which might have contributed towards soil acidity (Laxminarayana, 2010). The most important soil factors which control the different kinds of soil acidity are $\mathrm{pH}$, organic matter content and exchangeable and extractable aluminium (Sharma et al., 1990). Rainfall is the most important factor contributing towards removal of bases. Higher rainfall and free drainage favoured removal of bases to a maximum level and its deposition in the lower horizons contributed to the build up of significant amount of calcium in the subsoils.

Soil $\mathrm{pH}$ was measured potentiometrically in $\mathrm{H}_{2} \mathrm{O}$ and 1 mol L $\mathrm{L}^{-1} \mathrm{KCl}$ suspensions (1:2.5 soil: solution ratio), and the difference $\Delta \mathrm{pH}=\mathrm{pH} \mathrm{KCl}-\mathrm{pH} \mathrm{H}_{2} \mathrm{O}$ was used to estimate the sign of the net charge (Mekaru and Uehara, 1972; Steiner and Lana, 2013). The $\Delta \mathrm{pH}$ indicated that these soils contained appreciable quantity of clay minerals with relatively constant surface charges (Bleekar and Sageman, 1990). According to Van Wambede (1992), the amount of extractable Fe is usually greater in Ultisols than Oxisols. In Ultisols, the major source of exchangeable and titratable acidity were monomeric $\mathrm{Al}^{3+}$ and Al hydroxyl compounds (Pal et al., 2014). The less extractable acidity indicated the less degree of weathering and leaching of the profile (Natarajan, 1995).

\subsection{Lime management}

Based on the distribution of soil acidity, lime requirement was calculated and is given in Table 3. Results revealed that pedons $1,4,5$ and 6 requires more lime to neutralize surface soils than subsurface, whereas pedons 2 and 3 needs less lime. (Badrinath et al., 1997) pointed out that the current levels of cashew nut yield per tree are low and might be due to several factors which are limiting the economic yield. Hence, the application of inorganic fertilizers carrying P, K and Boron after the soil amelioration with dolomite lime stone will not only raises the soil $\mathrm{pH}$ but also favours the supplied plant nutrients in the available form to the plants (Laxminarayana, 2010).

\section{Conclusion}

The nature of soil acidity is mostly clay and $\mathrm{pH}$-dependent. Electro statistically bound $\mathrm{Al}^{3+}$ is the major contributing factor towards the exchange and extractable acidity. Exchange acidity showed highly significant relation with exchangeable $\mathrm{Al}^{3+}$ rather than with exchangeable $\mathrm{H}^{+}$. Thus could be managed through proper cultural practices, addition of lime materials and base fertilizers, which will restore nutrients availability and sustain the cashew production in coastal Karnataka.

\section{References}

Amenla, T., Sharma, Y.K., Sharma, S.K., 2010. Characterization of soils of Nagaland- with special reference to Mokokchung District. Environment and Ecology 28, 198-201.

Anonymous., 2003. Cashew Production Technology. National Research Centre for Cashew (NRCC), Technical bulletin, 5,36 .

Badrinath, M.S., Sudhir, K., Chikkaramappa, T., 1997. Soil fertility evaluation for cashew cultivation in coastal Karnataka soils. The cashew 11(2), 22-27.

Bhat, M.G., 2007. Annual report, National Research Centre for Cashew, 37-44.

Bhattacharyya, T., Sarkar, D., Sehgal, J.L., Velayutham, M., Gajbhiye, K.S., Nagar, A.P., Nimkhedkar, S.S., 2009. Soil Taxonomic Database of India and the States (1:250, 000 scale), NBSSLUP Publ. 143, NBSS\&LUP, Nagpur, India, (266).

Bleeker, P., Sageman, R., 1990. Surface charge characteristics and clay mineralogy of some variable charge soils of Papua New Guinea. Australian Journal of Soil Research 28, 901-917.

Chadha, K.L., Nair, M.K., 1998. Managing red and lateritic soils for sustainable agriculture, Red and lateritic soils (1), 179-189.

Chenithung, T., Tsanglao, Sharma., Y.K., Sharma, S.K., 2014. Fertility Status and Soil Acidity under Different Land Use Systems in Wokha District of Nagaland. Journal of the Indian Society of Soil Science 62(4), 414-418.

Dasog, G.S., Patil, P.L., 2002. Natural resources of coastal regions of Karnataka. In: Natural Resources of Coastal Regions of India. (T.M. Natarajan, G. Selvakumari and R. Sivasamy, Eds.) TNAU, Coimbatore, 141-155.

Dey, I.K., Sehgal, J.L., 1997. Clay mineralogy of some alluvial soils of Assam under long-term paddy cultivation. Agropedology 7, 48-53.

Hartemink, A.E., 2006. Soil Fertility Decline: Definitions and Assessment. Encyclopedia of Soil Science, 1618-1621.

Higgins, G.M., Kassam, A.H., 1983. The FAO Agro ecological zone approach to determining of land potential. Pedologie 31(2), 147-168.

Jackson, M. L., 1973. Soil chemical analysis, Prentice -Hall of India Pvt. Ltd. New Delhi, 40.

Laxminarayana, K., 2010. Nature of soil acidity and lime requirement in acid soils of Meghalaya. Journal of the Indian Society of Soil Science 58, 233-336.

Maji, AK., Obi Reddy, G.P., Sarkar, D., 2012. Acid soils of India - Their extent and spatial distribution, NBSSLUP Bulletin 145, NBSS \& LUP, Nagpur, India, 138. 
Mekaru, T., Uehara, G., 1972. Anion adsorption in ferruginous tropical soils. Soil Science Society of America Proceedings 36, 296-300.

Natarajan, A., 1995. Mineralogy and genesis of typical Lateritic soils in Peninsular India. Ph.D Thesis, submitted to UAS, GKVK, Bangalore-65.

Noble, A.D., Gillman, G.P., Ruaysoongnern, S., 2000. A Cation Exchange Index for assessing Degradation of acid soil by further aciditification under permanent agriculture in the Tropics. European journal of soil science 51, 233-243.

Pal, D.K., Wani, S.P., Sahrawat, K.L., Srivastava, P., 2014. Red ferruginous soils of tropical Indian environments: A review of the pedogenic processes and its implications for edaphology. Catena 121, 260-278.

Panda, N., 1987. Acid soils of Eastern India - Their chemistry and management. Journal of the Indian Society of Soil Science 35, 568-581.

Patton, S., Sharma, S.K., Singh, P.K., 2007. Characterization of the acidity of soils under different land use patterns in Nagaland. Journal of the Indian Society of Soil Science 55, 134-138.

Sanchez, P.A., 2002. Soil fertility and hunger in Africa. Science 295, 2019-2020.

Sarma, V.A.K., Krishnan, P., Budihal, S.L., 1987. Laboratory methods.NBSS pub.14, Technical Bulletin, National Bureau of Soil Survey and Land Use Planning, Nagpur, 49.

Sharma, P.D., Sarkar, A.K., 2005. Managing Acid Soils for Enhancing Productivity. Indian Council of Agricultural Research, NRM Division, Krishi Anusandhan Bhavan - II, New Delhi.
Sharma, S.P., Sharma, P.K., Tripathi, B.R., 1990. Forms of acidity in some acid soils of India. Journal of the Indian Society of Soil Science 41(2), 326-330.

Shivaprasad, C.R., Reddy, R.S., Sehgal, J., Velayutham, M., 1998. Soils of Karnataka for optimizing land use, National Bureau of Soil Survey and Land Use Planning, Nagpur, publication 47, 15.

Shoemaker, H.E., McLean, E.O., Pratt, P.F., 1961. Buffer methods for determining the lime requirement of soils with appreciable amounts of extractable aluminum. Soil Science Society of America Proceedings 25, 274-277.

Sivasankaran, K., Mithyanantha, M.S., Nateson, S., Subbarayappa, C.T., 1993. Physio-chemical properties and nutrient management of red and Lateritic soils under plantation crops in southern India. NBSS publ., 37, 280.

Steiner, F., Lana, M.C., 2013. Effect of $\mathrm{pH}$ on boron adsorption in some soils of Parana, Brazil. Chilean Journal of Agricultural Research 73(2), 181-186.

Talashilkar, S.C., Mehta,V.B., Dosani, A.A.K., Dhopavkar, R.V., Dhekale, J.S., 2006. Influence of Soil Reaction on Soil Acidity Parameters, and Fractions of Organic Matter, Nitrogen, Phosphorus and Potassium in Lateritic Soils of Konkan. Journal of the Indian Society of Soil Science 54(2), 174-178.

Thornthwaite, C.W., Mather, J.R., 1955. The water balance publn Climatology (8)1 Drexel Institute of Technology, Laboratory of Climatology, Centerten, New Jersey, USA, 104.

Van Wambeke, A., 1992. Soils of the tropics Properties and appraisal, MC Graw- Hill, 343. 